\title{
Chronic effects of soft drink consumption on the health state of Wistar rats: A biochemical, genetic and histopathological study
}

\author{
ADEL ALKHEDAIDE $^{1}$, MOHAMED MOHAMED SOLIMAN $^{1,2}$, ALAA-ELDIN SALAH-ELDIN $^{3,4}$ \\ TAMER AHMED ISMAIL ${ }^{1,5}$, ZAFER SAAD ALSHEHIRI $^{6}$ and HOSSAM FOUAD ATTIA ${ }^{7}$ \\ ${ }^{1}$ Department of Medical Laboratories, Faculty of Applied Medical Sciences, Taif 21944, Saudi Arabia; \\ ${ }^{2}$ Department of Biochemistry, Faculty of Veterinary Medicine, Benha University, Benha 13736, Egypt; \\ ${ }^{3}$ Medical Laboratories Department, College of Science, Majmaah University, Al Zulfi 2345, Saudi Arabia; \\ ${ }^{4}$ Department of Zoology, Faculty of Science at Aswan, Aswan University, Aswan 24101; ${ }^{5}$ Department of Physiology, \\ Faculty of Veterinary Medicine, Zagazig University, Zagazig 4655, Egypt; ${ }^{6}$ Medical Laboratory Department, \\ College of Applied Medical Sciences, Shaqra University, Al-Dawadmi 1678, Saudi Arabia; \\ ${ }^{7}$ Department of Histology, Faculty of Veterinary Medicine, Benha University, Benha 13736, Egypt
}

Received November 3, 2015; Accepted March 31, 2016

DOI: $10.3892 / \mathrm{mmr} .2016 .5199$

\begin{abstract}
The present study was performed to examine the effects of chronic soft drink consumption (SDC) on oxidative stress, biochemical alterations, gene biomarkers and histopathology of bone, liver and kidney. Free drinking water of adult male Wistar rats was substituted with three different soft drinks: Coca-Cola, Pepsi and 7-Up, for three consecutive months. The serum and organs were collected for examining the biochemical parameters associated with bone, liver and kidney functions. Semi-quantitative reverse transcription polymerase chain reaction was used to observe the changes in the expression of genes in the liver and kidney, which are associated with oxidative stress resistance. Histopathological investigations were performed to determine the changes in bone, liver and kidney tissues using hematoxylin and eosin stains. SDC affected liver, kidney and bone function biomarkers. Soft drinks increased oxidative stress, which is represented by an increase in malondialdehyde and a decrease in antioxidant levels. SDC affected serum mineral levels, particularly calcium and phosphorus. Soft drinks downregulated the expression levels of glutathione-S-transferase and super oxide dismutase in the liver compared with that of control rats. Rats administered Coca-Cola exhibited a hepatic decrease in the mRNA expression of $\alpha 2$-macroglobulin compared with rats administered Pepsi and 7-Up. On the other hand, SDC increased the mRNA expression of $\alpha 1$-acid glycoprotein. The present renal
\end{abstract}

Correspondence to: Professor Mohamed Mohamed Soliman, Department of Biochemistry, Faculty of Veterinary Medicine, Benha University, Al-Canal Street, Benha 13736, Egypt

E-mail: mohamed.soliman@fvtm.bu.edu.eg

Key words: soft drinks, chronic consumption, health state, molecular effects, histopathology studies revealed that Coca-Cola increased the mRNA expression levels of desmin, angiotensinogen and angiotensinogen receptor compared with the other groups, together with mild congestion in renal histopathology. Deleterious histopathological changes were reported predominantly in the bone and liver of the Coca-Cola and Pepsi groups. In conclusion, a very strict caution must be considered with SDC due to the increase in oxidative stress biomarkers and disruption in the expression of certain genes associated with the bio-vital function of both the liver and kidney.

\section{Introduction}

Soft drinks consumption (SDC) has increased worldwide in the past two-three decades (1). Their effects on health are unclear, although epidemiological studies pointed toward its associations with obesity, kidney, liver diseases and osteoporosis $(2,3)$. Soft drinks contain predominantly water, phosphoric acid, caffeine, sugar in the form of sucrose and other chemicals in the form of preservatives, colorings and flavors (2). The rate of SDC is alarming, particularly in the affluent countries (4). Numerous various health problems are associated with regular consumption of soft drinks (2). It has been shown that $\sim 25$ separate harmful effects are associated with SDC (2,3). Contents of soft drinks have a bad effect on human health (4). Caffeine in carbonated beverages is deliberately added to make individuals addicted, and is readily absorbed rapidly compared with any other drink (5).

A correlation exists between SDC and the incidence of multiple diseases, including obesity, dental/bone problems, diabetes mellitus and cardiovascular disease (6-9). Additionally, SDC is notbaly associated with kidney health and a high risk of kidney stone formation $(10,11)$. SDC causes bone fracture, disruption in bone formation, affects serum or urinary calcium metabolism markers and hypocalcemia, both in clinical and experimental settings (4,12-16). However, no significant association between SDC and the 
Table I. Primers used for polymerase chain reaction.

\begin{tabular}{|c|c|c|}
\hline Primer (product) & Sequence $\left(5^{\prime}-3^{\prime}\right)$ & Annealing conditions $\left({ }^{\circ} \mathrm{C}\right)$ \\
\hline \multicolumn{3}{|l|}{ IL-1 $\beta$ (550 bp) } \\
\hline Forward & TTCAAATCTCACAGCAGCATCT & \\
\hline Reverse & TGTGCAGACTCAAACTCCACTT & $60^{\circ} \mathrm{C}$ for $1 \mathrm{~min}$ \\
\hline \multicolumn{3}{|l|}{ AGP (325 bp) } \\
\hline Forward & GCTCCTGTCTGTTTCCTTAGTT & \\
\hline Reverse & GGCTTTTTGTTGTTTGCTTCTATTTC & $55^{\circ} \mathrm{C}$ for $1 \mathrm{~min}$ \\
\hline \multicolumn{3}{|l|}{ a2-MG (230 bp) } \\
\hline Forward & GCTCCTGTCTGTTTCCTTAGTT & \\
\hline Reverse & ATTGGCCTTTCGTGGTTTAG & $56^{\circ} \mathrm{C}$ for $1 \mathrm{~min}$ \\
\hline \multicolumn{3}{|l|}{ GST (575 bp) } \\
\hline Forward & GCTGGAGTGGAGTTTGAAGAA & \\
\hline Reverse & GTCCTGACCACGTCAACATAG & $55^{\circ} \mathrm{C}$ for $1 \mathrm{~min}$ \\
\hline \multicolumn{3}{|l|}{ SOD (410 bp) } \\
\hline Forward & AGGATTAACTGAAGGCGAGCAT & \\
\hline Reverse & TCTACAGTTAGCAGGCCAGCAG & $55^{\circ} \mathrm{C}$ for $1 \mathrm{~min}$ \\
\hline \multicolumn{3}{|l|}{ HO-1 (250 bp) } \\
\hline Forward & CTTGCAGAGAGAAGGCTACATGA & \\
\hline Reverse & AGAGTCCCTCACAGACAGAGTTT & $54^{\circ} \mathrm{C}$ for $1 \mathrm{~min}$ \\
\hline \multicolumn{3}{|l|}{ AGT (263 bp) } \\
\hline Forward & TTGTTGAGAGCTTGGGTCCCTTCA & \\
\hline Reverse & CAGACACTGAGGTGCTGTTGTCCA & $57^{\circ} \mathrm{C}$ for $1 \mathrm{~min}$ \\
\hline \multicolumn{3}{|l|}{ AT1 (440 bp) } \\
\hline Forward & GCACAATCGCCATAATTATCC & \\
\hline Reverse & CACCTATGTAAGATCGCTTC & $54^{\circ} \mathrm{C}$ for $1 \mathrm{~min}$ \\
\hline \multicolumn{3}{|l|}{ GAPDH (309 bp) } \\
\hline Forward & AGATCCACAACGGATACATT & \\
\hline Reverse & TCCCTCAAGATTGTCAGCAA & $52^{\circ} \mathrm{C}$ for $1 \mathrm{~min}$ \\
\hline
\end{tabular}

reduction of bone mineral density were reported in previous studies $(17,18)$. Therefore, the effect of SDC on bone, liver and renal health remains unknown and proper evidence is still required. The liver is the predominant organ in the human body that serves an essential role in the metabolism of food and drugs, and any alteration in its function induces deleterious effects. Additionally, the kidney is an organ whose functions in either the removal of metabolic waste products from the blood and water, or the regulation of electrolytes. The majority of published papers focused on biochemical alterations induced by soft drinks on the serum levels of hepatic and renal biomarkers.

In Saudi Arabia and the Middle East, individuals are used to drinking soft drinks on average 3 times per day with meals. Therefore, the present study aimed to examine the effect of chronic SDC (Coca-cola, Pepsi and 7-up) on oxidative stress biomarkers, histopathology of bone, liver and kidney and the expression of certain genes associated with liver and kidney functions, in order to outline its effect on the health of Wistar rats.

\section{Materials and methods}

Chemicals and kits. Ethidium bromide for agarose preparation and agarose were purchased from Sigma-Aldrich (St. Louis, MO, USA). A total of 40 male Wistar rats were purchased from King Abdel-Aziz University, King Fahd Center for Scientific Research (Jeddah, Saudi Arabia). Catalase, malondialdehyde (MDA), glutathione peroxidase (GSH-Px), glutathione reductase (GR), creatinine and urea kits were purchased from Bio Diagnostic Co. (Dokki, Egypt). Coca-Cola, Pepsi-cola and 7-Up were purchased from Taif markets in Saudi Arabia. The 100 bp DNA ladder marker was purchased from Fermentas (Thermo Fisher Scientific, Inc., Waltham, MA, USA). Oligo dT primer and Qiazol reagent were purchased from Qiagne (Valencia, CA, USA).

Experimental animals, design and sampling. The present study was approved by the Ethics Committee for the College of Applied Medical Sciences (Taif University; no. 3792/34/1). A total of 40 male Wistar rats (12-weeks-old; 
Table II. Serum changes in MDA, GSH-Px, GSH-R and catalase levels in rats following chronic consumption of soft drinks.

\begin{tabular}{lcccc}
\hline Condition & $\begin{array}{c}\text { MDA } \\
\text { (nmol/g protein) }\end{array}$ & $\begin{array}{c}\text { GSH-Px } \\
\text { (U/g protein) }\end{array}$ & $\begin{array}{c}\text { GSH-R } \\
(\text { U/g protein) }\end{array}$ & $\begin{array}{c}\text { Catalase } \\
(\text { U/g protein) }\end{array}$ \\
\hline Control & $32.7 \pm 2.7$ & $86.1 \pm 4.8$ & $75.4 \pm 4.2$ & $44.7 \pm 2.2$ \\
Cola & $63.7 \pm 7.6^{\mathrm{a}}$ & $57.9 \pm 5.2^{\mathrm{a}}$ & $54.7 \pm 4.6^{\mathrm{a}}$ & $28.6 \pm 1.4^{\mathrm{a}}$ \\
Pepsi & $96.7 \pm 9.8^{\mathrm{a}}$ & $36.3 \pm 5.8^{\mathrm{a}}$ & $34.2 \pm 6.0^{\mathrm{a}}$ & $17.3 \pm 1.9^{\mathrm{a}}$ \\
7-Up & $59.1 \pm 3.7^{\mathrm{a}}$ & $55.3 \pm 3.2^{\mathrm{a}}$ & $43.8 \pm 6.3^{\mathrm{a}}$ & $25.5 \pm 2.5^{\mathrm{a}}$ \\
\hline
\end{tabular}

The data are expressed as the mean \pm standard error of the mean ( $\mathrm{n}=3 /$ condition; ${ }^{\mathrm{a}} \mathrm{P}<0.05$ vs. control). GSH-Px, glutathione peroxidase; MDA, malondialdehyde; GSH-R, glutathione reductase.

Table III. Serum changes in glucose, urea, uric acid, creatinine, and total and direct bilrubin levels in rats following chronic consumption of soft drinks.

\begin{tabular}{lcccccc}
\hline Condition & $\begin{array}{c}\text { Glucose } \\
(\mathrm{mg} / \mathrm{dl})\end{array}$ & $\begin{array}{c}\text { Urea } \\
(\mathrm{mg} / \mathrm{dl})\end{array}$ & $\begin{array}{c}\text { Uric acid } \\
(\mathrm{mg} / \mathrm{dl})\end{array}$ & $\begin{array}{c}\text { Creatinine } \\
(\mathrm{mg} / \mathrm{dl})\end{array}$ & $\begin{array}{c}\text { Total bilirubin } \\
(\mathrm{mg} / \mathrm{dl})\end{array}$ & $\begin{array}{c}\text { Direct bilirubin } \\
(\mathrm{mg} / \mathrm{dl})\end{array}$ \\
\hline Control & $85.0 \pm 1.9$ & $36.3 \pm 3.5$ & $1.6 \pm 0.1$ & $0.40 \pm 0.01$ & $0.03 \pm 0.007$ & $0.024 \pm 0.004$ \\
Cola & $106.5 \pm 3.7^{\mathrm{a}}$ & $31.9 \pm 1.8$ & $1.9 \pm 0.2$ & $0.39 \pm 0.01$ & $0.06 \pm 0.006$ & $0.043 \pm 0.002$ \\
Pepsi & $120.8 \pm 5.1^{\mathrm{a}}$ & $32.8 \pm 1.9$ & $2.3 \pm 0.3^{\mathrm{a}}$ & $0.33 \pm 0.02$ & $0.10 \pm 0.009$ & $0.041 \pm 0.009$ \\
7-Up & $132.8 \pm 13.8^{\mathrm{a}}$ & $29.3 \pm 3.3$ & $2.4 \pm 0.3^{\mathrm{a}}$ & $0.27 \pm 0.01$ & $0.08 \pm 0.006$ & $0.028 \pm 0.007$ \\
\hline
\end{tabular}

The data are expressed as the mean \pm standard error of the mean ( $\mathrm{n}=3 /$ condition; ${ }^{\mathrm{a}} \mathrm{P}<0.05$ vs. control).

weight, 200-280 g). The rats were monitored daily and were maintained under observation for 1 week for complete acclimatization. The rats were maintained at $12 \mathrm{~h}$ light/dark cycles and received free access to food and water for the first week. The rats were then divided into four groups: i) Control without any treatment; ii) Coca-cola group; iii) Pepsi group; iv) 7-Up group. The rats in groups 2-4 received free access to the respective soft drinks for three consecutive months. At the end of experiment, all rats were anesthetized by diethyl ether inhalation. Blood and tissues were collected from anesthetized rats in sterilized vacutainer tubes. The serum was extracted following centrifugation of clotted blood for $15 \mathrm{~min}$ at $3,000 \mathrm{x} \mathrm{g}$ and was maintained at $-20^{\circ} \mathrm{C}$ until use. For gene expression analysis, hepatic and renal tissues were maintained at $-80^{\circ} \mathrm{C}$ in Qiazol reagent for RNA extraction. For histopathological examination, sections from the bone, liver and kidney were immersed overnight in neutral buffered formalin (NBF; 10\%) at room temperature.

Serum biochemical assays. MDA, GSH-Px, GSH-reductase (GSH-R), catalase, glucose, alkaline phosphatase (ALP), urea, bilirubin, creatinine, alanine transaminase (ALT), uric acid, aspartate transaminase (AST), creatine kinase (CK) and CKM were assayed spectrophotometrically using commercial kits purchased from Bio Diagnostic Co., according to the manufacturer's protocol. The levels of osteocalcin levels were assayed using enzyme-linked immunosorbent assay kits purchased from MyBioSource, LLC, San Diego, CA, USA). Various minerals, triglycerides (TG), cholesterol and high-dentisty lipoproteins (HDL) were assayed spectrophotometrically using kits imported from HUMAN Gesellschaft für Biochemica und Diagnostica mbH (Wiesbaden, Germany), according to the manufacturer's protocol. Serum lipase was measured using a lipase activity assay kit imported from Abcam (Cambridge, MA, USA).

cDNA preparation, synthesis and gene expression assessments. The total RNA from tissue samples was extracted, as previously described (19). The integrity of RNA was visualized and confirmed following running on a denatured agarose gel $(1.5 \%)$ stained with ethidium bromide. Oligo dT primer ( $0.5 \mathrm{ng}$ ) was added to $2 \mu \mathrm{g}$ total RNA to induce denaturation and was subsequently used for cDNA synthesis (19). For semi-quantitative gene expression analysis, specific primers were designed for certain genes, as illustrated in Table I, using Oligo 4 computer program (version 7; Molecular Biology Insights, Inc., Colorado Springs, CO, USA) and synthesized by (Macrogen Company, Geumcheon-gu. Korea). PCR was performed in a total volume of $25 \mu \mathrm{l}(1 \mu \mathrm{l} \mathrm{cDNA}, 1 \mu \mathrm{l} 10 \mathrm{pM}$ each primer, $12.5 \mu \mathrm{l}$ PCR master mix and $9.5 \mu 1$ sterilized, deionized water). A Bio-Rad $\mathrm{T} 100^{\mathrm{TM}}$ Thermal Cycle machine (Bio-Rad Laboratories, Inc., Hercules, CA, USA) was used for PCR, which was performed at $95^{\circ} \mathrm{C}$ for $4 \mathrm{~min}$, followed by 33 cycles of denaturation at $95^{\circ} \mathrm{C}$ for $50 \mathrm{sec}$, annealing as shown in Table I and extension at $72^{\circ} \mathrm{C}$ for 1 minute, with an additional final extension at $72^{\circ} \mathrm{C}$ for $5 \mathrm{~min}$. The expression of glyceraldehyde-3-phosphate dehydrogenase (GAPDH) was used as internal standard and as a reference gene. The PCR products were electrophoresed in a $1.5 \%$ agarose gel, followed by staining with ethidium bromide in Tris-Borate-EDTA buffer. The bands were visualized using an InGenius 3.0 gel documentation system (Syngene, Frederick, MD, USA) under UV light. 
Histopathology of bone, liver and kidney. Tissues from the bone, liver and kidney were dissected following diethyl ether inhalation and the sacrificing of the rats. The samples were immersed and fixed overnight in a $10 \%$ NBF solution. Bone, liver and kidney tissues were processed, washed and preserved in ethanol $(70 \%)$. The samples were subsequently dehydrated in ethanol solution in ascending grades, cleared with xylene, paraffin wax embedded, casted and cut into $5 \mu \mathrm{m}$ sections using microtome (Leica Microsystems, Inc., Buffalo Grove, IL, USA). Mayer's hematoxylin and eosin, and Masson's trichrome staining were used to stain the slides with the fixed tissue samples (20). The slides with tissue were examined using a Wolfe S9-0982 microscope (Carolina Biological Supply Company, Burlington, NC, USA) and images were captured using a Canon Power-Shot SX500 IS digital camera.

Statistical analysis. The data are presented as the mean \pm standard error of the mean. Analysis of variance was used to analyze data together with post hoc descriptive tests using SPSS 11.5 for Windows (SPSS, Inc., Chicago, IL, USA). $\mathrm{P}<0.05$ was considered to indicate a statistically significant difference. The intensities of the bands were quantified densitometrically using Image $\mathbf{J}$ software (version 1.47) and were matched compared to the control group and expressed as a percent (http://imagej.en.softonic.com/).

\section{Results}

Effect of SDC for 3 months on the serum levels of MDA, $G S H-P x$, catalase and GSH-R in Wistar rats. SDC for 3 months revealed an increase in MDA levels (Table II) with a highly significant effect on Pepsi-administered rats compared with the control rats. By contrast, the antioxidant activity of GSH-Px, catalase and GSH-R in the rats were decreased significantly in all SDC groups (Table II).

Effect of SDC for 3 months on the blood levels of glucose, hepatic and renal biomarkers in Wistar rats. SDC for 3 months, significantly increased the serum levels of glucose and moderately increased uric acid and bilirubin in the Coca-Cola, Pepsi and 7-up groups compared with the control group (Table III).

Effect of SDC for 3 months on serum levels of hepatic biomarkers in Wistar rats. SDC for 3 months significantly increased the levels of liver biomarkers, with a more marked effect on AST and a moderate effect on ALT. Additionally, ALP increased in all groups compared with the control rats (Table IV).

Effect of SDC for 3 months on the serum levels of minerals and osteocalcin in Wistar rats. SDC decreased both calcium and iron levels in the rats. By contrast soft drinks increased serum phosphorous levels. In addition, soft drinks revealed no effect sodium and chloride levels. Notably, soft drinks increased the levels of osteocalcin (Table V).

Effect of SDC for 3 months on the serum levels of lipase and lipid profiles in Wistar rats. SDC increased serum lipase levels, which resulted in a decrease in cholesterol and TG levels in
Table IV. Serum changes in AST, ALT and ALP levels in rats following chronic consumption of soft drinks.

\begin{tabular}{llll}
\hline Condition & AST (U/l) & ALT (U/1) & ALP (U/1) \\
\hline Control & $130.6 \pm 2.6$ & $55.4 \pm 2.8$ & $155.5 \pm 2.6$ \\
Cola & $158.1 \pm 9.5^{\mathrm{a}}$ & $68.6 \pm 3.0^{\mathrm{a}}$ & $246.1 \pm 20.5^{\mathrm{a}}$ \\
Pepsi & $212.7 \pm 31.4^{\mathrm{b}}$ & $84.9 \pm 3.5^{\mathrm{b}}$ & $196.8 \pm 20^{\mathrm{b}}$ \\
$7-\mathrm{Up}$ & $145.9 \pm 12.1$ & $60.4 \pm 3.7$ & $202.5 \pm 11.2$ \\
\hline
\end{tabular}

The data are expressed as the mean \pm standard error of the mean ( $\mathrm{n}=3 /$ condition; ${ }^{\mathrm{a}} \mathrm{P}<0.05$; ${ }^{\mathrm{b}} \mathrm{P}<0.01 \mathrm{vs}$. control). ALT, alanine transaminase; ALP, alkaline phosphatase; AST, aspartate transaminase.

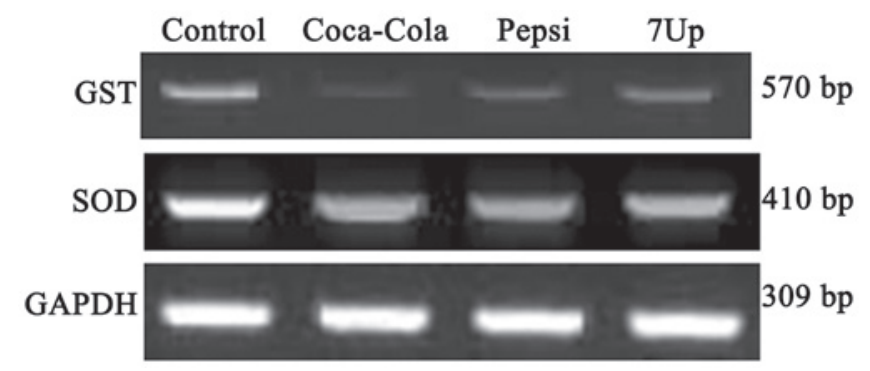

Figure 1. Semi-quantitative reverse-transcription polymerase chain reaction analysis of GST and SOD in liver tissues of Wistar rats following chronic administration of soft drinks for 3 months. GST, glutathione S-transferase; SOD, superoxide dismutase; GAPDH, glyceraldehyde-3-phosphate dehydrogenase.

the SDC groups compared with the control (Table VI). By contrast, HDL was decreased in the Coca-Cola and Pepsi groups compared with the control group; however, 7-Up caused no effect.

Effect of SDC for 3 months on the mRNA expression levels of GST and SOD in the liver of Wistar rats. SDC for 3 months downregulated the gene expression levels of GST and SOD (Fig. 1). The expression percentage of GST was $\sim 80,60$ and 40\% decreased in Coca-Cola, Pepsi and 7-Up groups, respectively. All groups exhibited a slight downregulation in the mRNA expression of SOD in hepatic tissue at a percentage of 30,18 and $15 \%$, respectively, compared with the control rats.

Effect of SDC for 3 months on the mRNA expression levels of $\alpha 1-A G P$ and $\alpha 2-M G$ in the liver of Wistar rats. SDC significantly upregulated the mRNA expression of $\alpha 1$-AGP in the liver tissues (Fig. 2). The percentage of upregulation in the expression of $\alpha 1$-AGP was 66,70 and $75 \%$ for Coca-Cola, Pepsi and 7-Up, respectively. By contrast, the expression of $\alpha 2-\mathrm{MG}$ was downregulated by Coca-Cola (45\%) and moderately upregulated in the Pepsi and 7-Up groups by 15 and $20 \%$, respectively, compared with the control rat (Fig. 2).

Effect of SDC for 3 months on the mRNA expression levels of genes associated with renal function biomarkers and stability in Wistar rats. Next, the present study tested 
Table V. Serum changes in mineral levels in rats following chronic consumption of soft drinks.

\begin{tabular}{|c|c|c|c|c|c|c|c|c|}
\hline Condition & $\begin{array}{c}\mathrm{Ca} \\
(\mathrm{mg} / \mathrm{dl})\end{array}$ & $\begin{array}{c}\mathrm{P} \\
(\mathrm{mg} / \mathrm{dl})\end{array}$ & $\begin{array}{c}\mathrm{Cl} \\
(\mathrm{nmol} / \mathrm{l})\end{array}$ & $\begin{array}{c}\mathrm{Fe} \\
(\mu \mathrm{g} / \mathrm{dl})\end{array}$ & $\underset{(\mathrm{nmol} / \mathrm{l})}{\mathrm{K}}$ & $\begin{array}{c}\mathrm{Mg} \\
(\mathrm{mg} / \mathrm{dl})\end{array}$ & $\begin{array}{c}\mathrm{Na} \\
(\mathrm{nmol} / \mathrm{l})\end{array}$ & $\begin{array}{l}\text { Osteocalcin } \\
(\mathrm{ng} / \mathrm{ml})\end{array}$ \\
\hline Control & $11.6 \pm 0.3$ & $5.3 \pm 0.2$ & $88.7 \pm 1.2$ & $342.6 \pm 34.2$ & $9.8 \pm 0.1$ & $2.7 \pm 0.1$ & $134.8 \pm 2.1$ & $39.1 \pm 2.9$ \\
\hline Cola & $9.3 \pm 0.2^{\mathrm{a}}$ & $6.8 \pm 0.6$ & $96.1 \pm 0.9^{a}$ & $233.4 \pm 17.8^{a}$ & $9.9 \pm 0.6$ & $2.2 \pm 0.1$ & $132.3 \pm 0.5^{\mathrm{a}}$ & $60.5 \pm 4.6$ \\
\hline Pepsi & $9.4 \pm 0.0^{\mathrm{a}}$ & $7.9 \pm 0.4^{\mathrm{a}}$ & $96.2 \pm 0.2^{\mathrm{a}}$ & $201.1 \pm 21.7^{\mathrm{a}}$ & $11.7 \pm 1.0^{\mathrm{a}}$ & $2.4 \pm 0.1$ & $131.3 \pm 1.4^{b}$ & $80.4 \pm 7.8$ \\
\hline 7-Up & $9.6 \pm 0.3^{\mathrm{a}}$ & $7.4 \pm 0.8^{a}$ & $96.0 \pm 0.6^{\mathrm{a}}$ & $256.4 \pm 21.9^{a}$ & $12.7 \pm 0.2^{\mathrm{a}}$ & $2.3 \pm 0.1$ & $130.3 \pm 0.6$ & $60.8 \pm 4.8$ \\
\hline
\end{tabular}

The data are expressed as the mean \pm standard error of the mean $\left(\mathrm{n}=3 /\right.$ condition; ${ }^{\mathrm{a}} \mathrm{P}<0.05$; ${ }^{\mathrm{b}} \mathrm{P}<0.01 \mathrm{vs}$. control).

Table VI. Serum changes in lipid profiles and lipase levels in rats following chronic consumption of soft drinks.

\begin{tabular}{lcccc}
\hline Condition & Lipase (U/l) & Cholesterol $(\mathrm{mg} / \mathrm{dl})$ & TG $(\mathrm{mg} / \mathrm{dl})$ & HDL-C (mg/dl) \\
\hline Control & $4.6 \pm 0.6$ & $59.9 \pm 2.0$ & $182.3 \pm 8.3$ & $44.6 \pm 1.6$ \\
Cola & $5.9 \pm 0.9^{\mathrm{a}}$ & $41.4 \pm 2.9^{\mathrm{a}}$ & $115.3 \pm 11.8^{\mathrm{a}}$ & $29.1 \pm 3.9^{\mathrm{a}}$ \\
Pepsi & $5.8 \pm 0.1^{\mathrm{a}}$ & $43.2 \pm 2.7^{\mathrm{a}}$ & $78.6 \pm 8.3^{\mathrm{a}}$ & $33.1 \pm 2.9^{\mathrm{a}}$ \\
7-Up & $5.4 \pm 0.2$ & $56.2 \pm 1.0$ & $92.4 \pm 14.9^{\mathrm{a}}$ & $43.8 \pm 1.8$ \\
\hline
\end{tabular}

The data are expressed as the mean \pm standard error of the mean ( $\mathrm{n}=3 /$ condition; ${ }^{\mathrm{P}} \mathrm{P}<0.05$ vs. control). TG, triglycerides; HDL, high-density lipopolysaccharides.

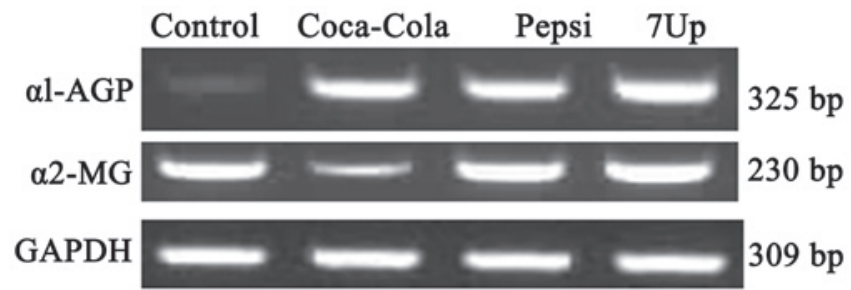

Figure 2. Semi-quantitative reverse-transcription polymerase chain reaction analysis of $\alpha 1$-AGP and $\alpha 2-\mathrm{MG}$ in the liver tissues from Wistar rats following chronic administration of soft drinks for 3 months. AGP, acid glycoprotein; MG, macroglobulin; GAPDH, glyceraldehyde-3-phosphate dehydrogenase.

the effect of SDC on the mRNA expression levels of certain genes associated with normal kidney function and stability. The expression of desmin was upregulated in the Coca-Cola-, Pepsi- and 7-Up-administered rats at a percentage of 75, 50 and 60\%, respectively (Fig. 3). Interleukin (IL)-1 $\beta$ was only increased in the Pepsi and 7-Up groups by 30 and $50 \%$, respectively. The expression of homooxygenase (HO)-1 was only increased in the Coca-Cola and 7-Up groups by 90 and 25\%, respectively. The present study also examined the genes associated with blood pressure, including angiotensinogen (AT) and its receptor (AT-R). The expression of AT was upregulated in the Coca-Cola group (55\% increase compared with the control). The expression of AT-R was also upregulated by 64 and $10 \%$ for Cola and Pepsi, respectively, compared with the control and 7-Up groups (Fig. 3).

Effect of SDC for 3 months on bone, liver and kidney histopathology. The bone consisted of numerous bony lamellae, and bone marrow extended between these lamella. The blood

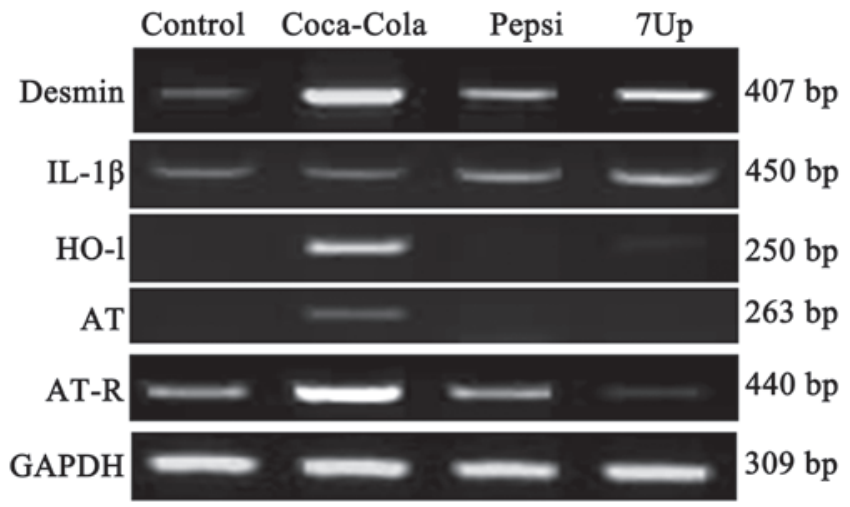

Figure 3. Semi-quantitative reverse-transcription polymerase chain reaction analysis of genes linked with kidney function and stability in Wistar rats following chronic administration of soft drinks for three months. IL. interleukin; HO, heme oxygenase; AT, angiotensin; AT-R, AT receptor; GAPDH, glyceraldehyde-3-phosphate dehydrogenase.

progenitor cells occupied the architecture of the bone marrow. The structure unit of the bone consisted of osteocytes arranged around the haversian canal (Fig. 4A). In the Coca-Cola and Pepsi groups, the bone lamella exhibited dark acidophilic areas in the bone architecture due to calcium withdrawal, while the other parts exhibited faint basophilic patches (Fig. 4B and C). In the 7-Up group, the bone lamella exhibited little histological changes in the form of small patches of faint basophilic areas (Fig. 4D).

The liver consisted of a central vein, which was surrounded by numerous hepatic cords. The hepatic cords were synthesized from polygonal hepatic cells with acidophilic cytoplasm and basophilic nuclei, which were centrally located. Von Kupffer cells were located between the hepatic 


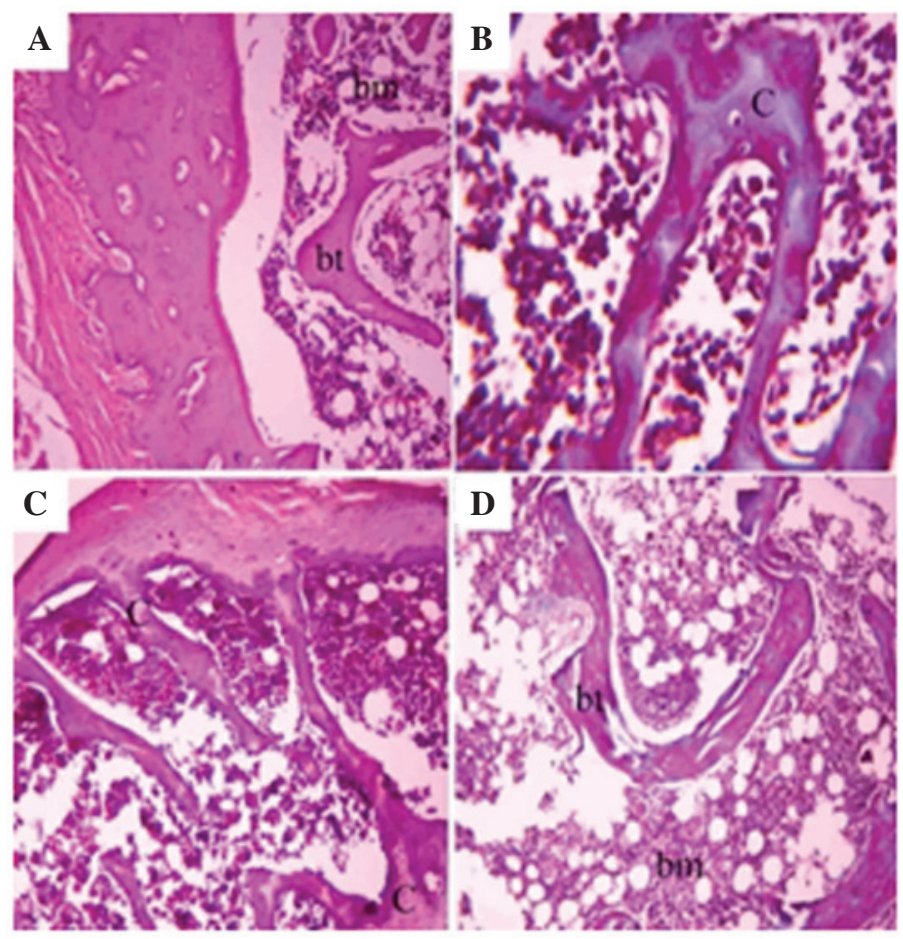

Figure 4. Photomicrographs of the Wistar rat bone following staining. (A) Staining with hematoxylin and eosin revealed bt and bm (magnification, x10). Masson's trichrome staining demonstrated (B) the bone to exhibit dark acidophilic patches and faint basophilic patches (magnification, x10). (C) Staining wtih Masson trichrome revealed dark acidophilic and faint basophilic patches (magnification, x40) and (D) the bone exhibited small faint basophilic patches (magnificaiton, x10). bt, bone lamellae; bm, bone marrow.
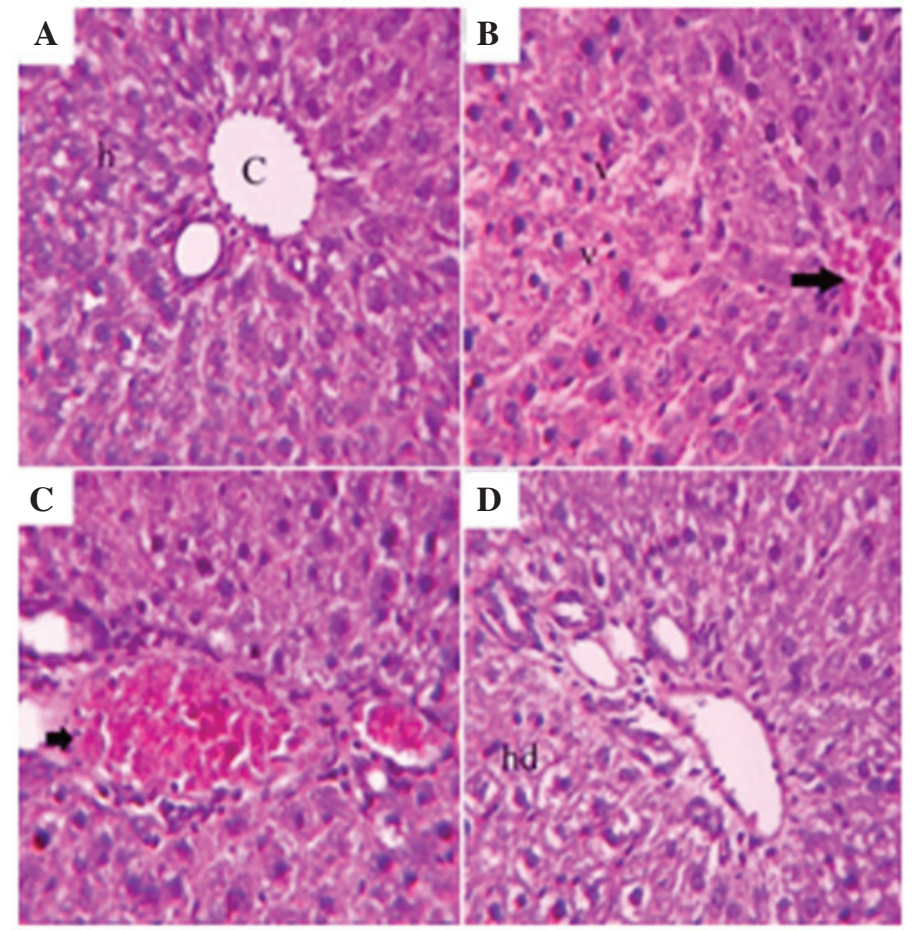

Figure 5. Photomicrograph of the Wistar rat liver following staining with hematoxylin and eosin. (A) Staining of control smples revealed $\mathrm{c}$ and $\mathrm{h}$ (magnification, $\mathrm{x} 10$ ), and the (B) vonkupher cells exhibited $\mathrm{v}$ and congestion in the blood vessels in the Coco Cola group (arrow; magnification, x10). (C) In the Pepsi group the liver blood vessels exhibited severe congestion (arrow; magnification, x10). (D) In the 7-Up group hd was observed in the hepatic cells (magnification, $\mathrm{x} 10)$. c, central vein; h, hepatic cords; $\mathrm{v}$, activation; hd, hydropic degeneration.

cords (Fig. 5A). In the Coca-Cola group, the liver exhibited activation of Von Kupffer cells and congestion in the blood vessels (Fig. 5B). The liver of the Pepsi group exhibited congestion in blood vessels (Fig. 5C). In the 7-up group, the liver exhibited hydropic degeneration, in addition to congestion of the blood vessels (Fig. 5D). 


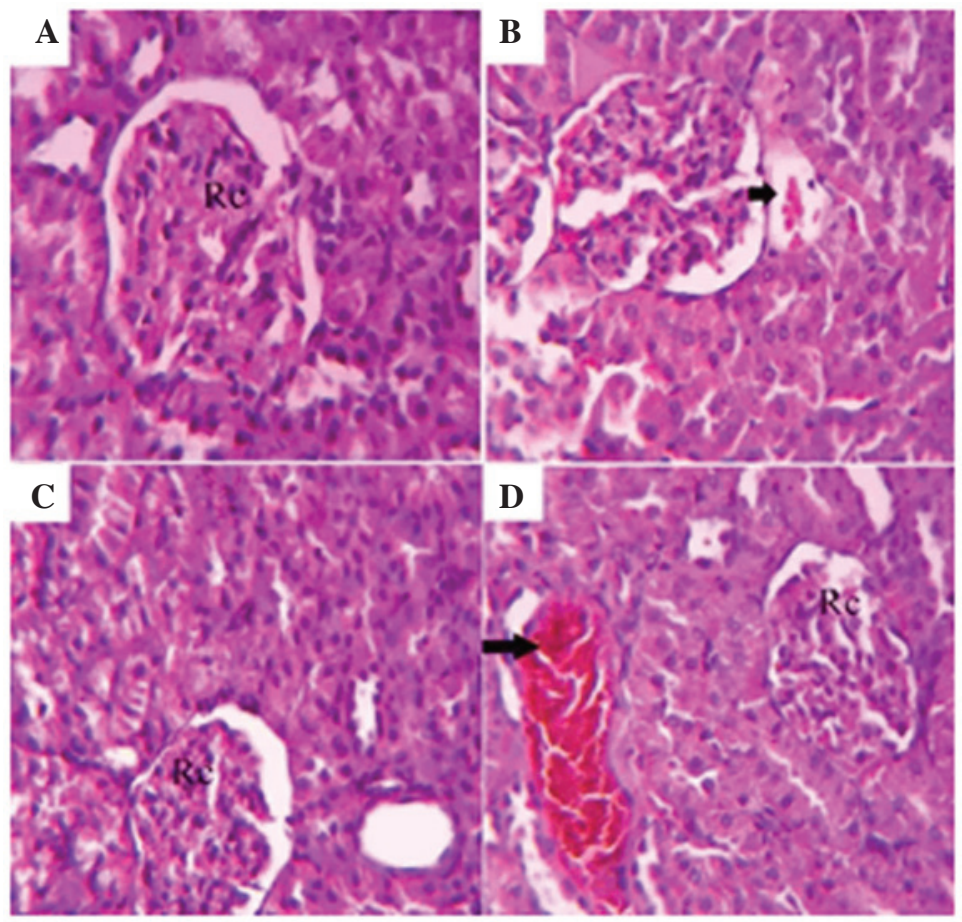

Figure 6. Photomicrograph of the Wistar rat kidney following staining with hematoxylin and eosin. (A) Rc, and proximal and distal convoluted tubules were observed in control samples (magnification, x40). (B) Congestion in the renal blood vessels (arrow) was also observed in the Coca Cola group (magnification, $\mathrm{x} 40$ ). (C) The renal tissues exhibited no histological changes in the Pepsi group (magnification, $\mathrm{x} 40$ ). (D) The renal blood vessels exhibited severe congestion in the 7-Up group (arrow; magnification, $\mathrm{x} 40$ ). Rc, renal corpuscle.

The kidney of the control group consisted of renal corpuscle, surrounded by proximal and distal convoluted tubules (Fig. 6A). In all soft drink groups, the renal tissues exhibited mild congestion in the renal blood vessels (Fig. 6B-D).

\section{Discussion}

The results of the present study confirmed that chronic SDC induced oxidative stress, metabolic alterations and changes in gene expression in Wistar rats. Oxidative stress has been associated with the etiology and pathogenesis of various chronic diseases and serves a vital role in the aging process (21). High levels of free radicals or reactive oxygen species (ROS) can cause direct damage to lipids inside cells and induce peroxidation (21). The primary sources of endogenous ROS production are the mitochondria, plasma membrane, endoplasmic reticulum and peroxisomes through a variety of mechanisms, including enzymatic reactions and/or auto-oxidation of several compounds, including catecholamines and hydroquinone (22). Chronic SDC-induced oxidative stress, which may cause hepatic toxicity, is indicated by the increase in MDA and the decrease in GSH-Px, GSH-R and catalase levels, as well as the decrease in the mRNA expression levels of GST and SOD. Soft drinks are the predominant source of sugar worldwide and are associated with obesity in children and adolescents. Soft drinks favor the incidence of insulin resistance and inflammation, and other diseases, including obesity, type-2 diabetes, dental caries, osteoporosis and low nutrient level (23-25).

The present study hypothesized that SDC is associated with lower bone mineral density, as indicated by the disturbance in minerals levels that is likely due to its caffeine contents, which is a predisposing factor for osteoporosis incidence $(5,26,27)$. In addition, phosphoric acid interferes with absorption of calcium and increases the loss of calcium (5). Additionally, high fructose may negatively affect bone stability (28). The increase in glucose reported in the present results is due to presence of caffeine in soft drinks. Caffeine causes the release of adrenaline and the increase in blood glucose to counteract the requirement for energy during emergency $(3,5)$. SDC caused liver injuries that are followed by the increase in the activities of GPT and GOT (29). Alkaline phosphatase increase is considered as a bone remodeling marker. The increase in AP is due to the presence of caffeine in soft drinks (30). Caffeine affects the biosynthesis of AP and inhibits the formation of a competent extracellular matrix, essential for bone remodling $(30,31)$. Additionally, the increase in osteocalcin that serves a role in mineralization of bone and calcium homeostasis cannot be neglected (32). It has been previously shown that heavy SDC is associated with hypocalcemia, and alterations in liver enzymes and histology in non-alcoholic fatty liver disease, both in clinical and experimental settings $(5,12,13,33,34)$.

The explanation of mineral metabolism disorders is due to high phosphate intake as exogenous phosphate loads inhibits renal $1 \alpha$-hydroxylase and reduces vitamin $D$ biosynthesis (35). Therefore, the increase in phosphate hinders both intestinal absorption and renal calcium re-absorption causing hypocalcemia (36). Consequently, hyperparathyroidism is developed, however, this is not enough to prevent sustained hypocalcemia (36). This explains why heavy SDC is characterized by hypocalcemia, hyperparathyroidism and reduced $1 \alpha-25$-dihy droxyvitamin D level $(5,12)$. In parallel, SDC decreased iron absorption in the intestine, as explained in the present and a previous study (37). In addition, acidemia occurred when SDC increases bone resorption and calcium mobilization, and 
reduces $1 \alpha$-hydroxylase activity and vitamin $\mathrm{D}$ production in kidney (38-40).

$\alpha 1$-AGP is a protein of acute phase stage, synthesized predominantly in hepatic cells and is regulated by pregnancy, drugs and certain diseases, and is increased during inflammation (41). The present study reported that SDC increased the mRNA expression of $\alpha 1-\mathrm{AGP}$, as a result of hepatic cells injury. Additionally, $\alpha-2 \mathrm{MG}$ is slightly decreased in response to Coca-Cola and increased in response to Pepsi and 7-Up. $\alpha-2 \mathrm{MG}$ upregulation is probably a reversed mechanism to prohibit plasmin biosynthesis and to facilitate the transport of growth factors, which assist in the regeneration of hepatocytes due to hepatic congestion reported in histopathological findings (42). Renal podocytes are essential components of the kidney, which maintain normal glomerular structure. Podocytes regulate filtration flow through the intracellular spaces, and they are situated at the basement of glomeruli and act as ultrafilteration barrier $(43,44)$. Focal segmental glomerulosclerosis and chronic renal diseases are caused by podocyte injury (45).

SDC upregulated the expression levels of desmin and HO-1 and angiotensinogen. Desmin upregulation is indicative for inflammation in the intrafilament proteins (46). HO-1 assists in the oxidation of heme producing active molecules (carbon monoxide, biliverdin and ferrous ion) that serve as a second messenger to control various cellular functions (47). Upregulation of HO-1 causes inhibition of either effectors of immune functions or adaptive response to various body injuries (48). The upregulation in the expression of IL- $1 \beta$ is proceeded by an increase in the expression of HO-1. Development of hypertension, renal oxidative stress and tissue injury are due to an increase in AGT biosynthesis, secretion and excretion (49). Of interest, the changes reported in the expression levels of AT-1 and AGT were due to changes in oxidative stress and renal injuries resulting from SDC, as confirmed by renal congestion. Bone is the most examined organ affected histopathologically due to minerals metabolism disorder, as reported in the present and other previous studies $(16,18,26,27)$. The kidney and liver histopathological alterations reported are moderate degenerative changes, which resulted in the changes in gene expression of both the kidney and liver. Taken together, these data confirmed that SDC induced biochemical and genetic alterations in examined organs, although less histopathological changes reported in the bone, liver and kidney.

\section{Acknowledgements}

The present study was supported by a grant in aid for Mohamed Mohamed Soliman of the Deans of Scientific Research Affairs, Taif University, Saudi Arabia (no. 3792-1436).

\section{References}

1. Nielsen SJ and Popkin BM: Changes in beverage intake between 1977 and 2001. Am J Prev Med 27: 205-210, 2004.

2. Adjene JO, Ezeoke JC and Nwose EU: Histological effects of chronic consumption of soda pop drinks on kidney of adult Wister rats. N Am J Med Sci 2: 215-217, 2010.

3. Amato D, Maravilla A, García-Contreras F and Paniagua R: Soft-drinks and health. Rev Invest Clin 49: 387-395, 1997 (In Spanish).
4. Amato D, Maravilla A, Montoya C, Gaja O, Revilla C, Guerra R and Paniagua R: Acute effects of soft drink intake on calcium and phosphate metabolism in immature and adults rats. Rev Invest Clin 50: 185-189, 1998.

5. Rapuri PB, Gallagher JC, Kinyamu HK and Ryschon KL: Caffeine intake increases the rate of bone loss in elderly women and interacts with vitamin D receptor genotypes. Am J Clin Nutr 74: 694-6700, 2001.

6. Fung TT, Malik V, Rexrode KM, Manson JE, Willett WC and Hu FB: Sweetened beverage consumption and risk of coronary heart disease in women. Am J Clin Nutr 89: 1037-1042, 2009.

7. Palmer JR, Boggs DA, Krishnan S, Hu FB, Singer M and Rosenberg L: Sugar-sweetened beverages and incidence of type 2 diabetes mellitus in African American women. Arch Intern Med 168: 1487-1492, 2008.

8. Swinburn BA, Caterson I, Seidell JC and James WP: Diet, nutrition and the prevention of excess weight gain and obesity. Public Health Nutr 7: 123-146, 2004.

9. Yip HH, Wong RW and Hägg U: Complications of orthodontic treatment: Are soft drinks a risk factor? World J Orthod 10: 33-40, 2009.

10. Ferraro PM, Taylor EN, Gambaro G and Curhan GC: Soda and other beverages and the risk of kidney stones. Clin J Am Soc Nephrol 8: 1389-1395, 2013.

11. Passman CM, Holmes RP, Knight J, Easter L, Pais V and Assimos DG: Effect of soda consumption on urinary stone risk parameters. J Endourol 23: 347-350, 2009.

12. Fernando GR, Martha RM and Evangelina R: Consumption of soft drinks with phosphoric acid as a risk factor for the development of hypocalcemia in postmenopausal women. J Clin Epidemiol 52: 1007-1010, 1999.

13. Mazariegos-Ramos E, Guerrero-Romero F, Rodríguez-Morán M, Lazcano-Burciaga G, Paniagua R and Amato D: Consumption of soft drinks with phosphoric acid as a risk factor for the development of hypocalcemia in children: A case control study. J Pediatr 126: 940-942, 1995.

14. Petridou E, Karpathios T, Dessypris N, Simou E and Trichopoulos D: The role of dairy products and non-alcoholic beverages in bone fractures among schoolage children. Scand J Soc Med 25: 119-125, 1997.

15. Smith S, Swain J, Brown EM, Wyshak G, Albright T, Ravnikar VA and Schiff I: A preliminary report of the short term effect of carbonated beverage consumption on calcium metabolism in normal women. Arch Intern Med 149: 2517-2519, 1989.

16. Teófilo JM, Leonel DV and Lamano T: Cola beverage consumption delays alveolar bone healing: A histometric study in rats. Braz Oral Res 24: 177-181, 2010.

17. Kim SH, Morton DJ and Barrett-Connor EL: Carbonated beverage consumption and bone mineral density among older women: The Rancho Bernardo study. Am J Public Health 87: 276-279, 1997.

18. García-Contreras F, Paniagua R,Avila-Díaz M,Cabrera-MuñozL, Martínez-Muñiz I, Foyo-Niembro E and Amato D: Cola beverage consumption induces bone mineralization reduction in ovariectomized rats. Arch Med Res 31: 360-365, 2000.

19. Soliman MM, Baiyoumi AA and Yassin MH: Molecular and histopathological study on the ameliorative effects of curcumin against lead acetate-induced hepatotoxicity and nephrototoxicity in Wistar rats. Biol Trace Elem Res 167: 91-102, 2015.

20. Bancroft JD and Gamble M (eds): Theory and practice of histological techniques. 6th edition. Churchill Livingstone Elsevier, Philadelphia, pp126-127, 2008.

21. Moldovan L and Moldovan NI: Oxygen free radicals and redox biology of organelles. Histochem Cell Biol 122: 395-412, 2004.

22. Higgins JP, Tuttle TD and Higgins CL: Energy beverages: Content and safety. Mayo Clin Proc 85: 1033-1041, 2010.

23. Gaby AR: Adverse effects of dietary fructose. Altern Med Rev 10: 294-306, 2005.

24. Assy N, Nasser G, Kamayse L, Nseir W, Beniashvili Z, Djibre A and Grosovski M: Soft drink consumption linked with fatty liver in the absence of traditional risk factors. Can J Gastroeterol 22: 811-816, 2008.

25. Vartaman LR, Schwartz MB and Brownwell KD: Effects of soft drink consumption on nutrition and health: A systematic review and meta-analysis. Am J Public Health 97: 667-675, 2007.

26. Hernández-Avila M, Stampfer MJ, Ravnikar VA, Willett WC, Schiff I, Francis M, Longcope C, McKinlay SM and Longscope C (corrected to Longcope C): Caffeine and other predictors of bone density among pre- and perimenopausal women. Epidemiology 4 : 128-134, 1993 . 
27. Massey LK and Whiting SJ: Caffeine, urinary calcium, calcium metabolism and bone. J Nutr 123: 1611-1614, 1993.

28. Milne DB and Nielsen FH: The interaction between dietary fructose and magnesium adversely affects macromineral homeostasis in men. J Am Coll Nutr 19: 31-37, 2000.

29. Jeroh E, Awhin EP, Osadem L and Awire EI: Effect of carbonated drinks on the activities of Alanine Aminotransferase (ALT) and Aspartate Aminotransferase (AST) in serum and kidney in Rattus novergicus. Asian J Biochem 7: 59-62, 2012.

30. Casiglia E, Spolaore P, Ginocchio G and Ambrosio GB: Unexpected effects of coffee consumption on liver enzymes. Eur J Epidemiol 9: 293-297, 1993.

31. Tassinari MS, Gerstenfeld LC, Stein GS and Lian JB: Effect of caffeine on parameters of osteoblast growth and differentiation of a mineralized extracellular matrix in vitro. J Bone Miner Res 6: 1029-1036, 1991

32. Kanazawa I, Yamaguchi T, Yamamoto M, Yamauchi M, Yano S and Sugimoto T: Serum osteocalcin/bone-specific alkaline phosphatase ratio is a predictor for the presence of vertebral fractures in men with type 2 diabetes. Calcif Tissue Int 85 : 228-234, 2009.

33. Abid A, Taha O, Nseir W, Farah R, Grosovski M and Assy N: Soft drink consumption is associated with fatty liver disease independent of metabolic syndrome. J Hepatol 51: 918-924, 2009.

34. Ohta M, Cheuk G, Thomas KA, Kamagata-Kiyoura Y, Wink CS, Yazdani M, Falster AU, Simmons WB and Nakamoto T: Effect of caffeine on the bones of aged, ovariectomized rats. Ann Nutr Metab 43: 52-59, 1999.

35. Portale AA, Halloran BP, Murphy MM and Morris RC Jr: Oral intake of phosphorus can determine the serum concentration of 1,25-dihydroxyvitamin $\mathrm{D}$ by determining its production rate in humans. J Clin Invest 77: 7-12, 1986.

36. Haussler MR and McCain TA: Basic and clinical concepts related to vitamin D metabolism and action (first of two parts). N Engl J Med 297: 974-983, 1977.

37. Hallberg L and Rossander L: Effect of different drinks on the absorption of non-heme iron from composite meals. Hum Nutr Appl Nutr 36: 116-123, 1982.
38. Lemann J Jr and Lennon EJ: Role of diet, gastrointestinal tract and bone in acid base homeostasis. Kidney Int 1: 275-279, 1972.

39. Hintz HF: Calcium, cola, calamity. Cornell Vet 70: 3-9, 1980

40. Celec P, Pálffy R, Gardlík R, Behuliak M, Hodosy J, Jáni P, Bozek P and Sebeková K: Renal and metabolic effects of three months of decarbonated cola beverages in rats. Exp Biol Med (Maywood) 235: 1321-1327, 2010.

41. Anderson SP, Cattley RC and Corton JC: Hepatic expression of acute-phase protein genes during carcinogenesis induced by peroxisome proliferators. Mol Carcinog 26: 226-238, 1999.

42. Lyoumi S, Tamion F, Petit J, Déchelotte P, Dauguet C, Scotté M, Hiron M, Leplingard A, Salier JP, Daveau M and Lebreton JP: Induction and modulation of acute-phase response by protein malnutrition in rats: Comparative effect of systemic and localized inflammation on interleukin- 6 and acute-phase protein synthesis. J Nutr 128: 166-174, 1998.

43. Fries JW, Sandstrom DJ, Meyer TW and Rennke HG: Glomerular hypertrophy and epithelial cell injury modulate progressive glomerulosclerosis in the rat. Lab Invest 60: 205-218, 1989.

44. Kriz W, Gretz N and Lemley KV: Progression of glomerular diseases: Is the podocyte the culprit? Kidney Int 54: 687-697, 1998.

45. DePianto D and Coulombe PA: Intermediate filaments and tissue repair. Exp Cell Res 301: 68-76, 2004.

46. Omary MB, Coulombe PA and McLean WH: Intermediate filament proteins and their associated diseases. N Engl J Med 351: 2087-2100, 2004.

47. Ryter SW, Alam J and Choi AM: Heme oxygenase1/carbon monoxide: From basic science to therapeutic applications. Physiol Rev 86: 583-650, 2006.

48. Bach FH: Heme oxygenase-1 as a protective gene. Wien Klin Wochenschr 114 (Suppl 4): S1-S3, 2002

49. Lara LS, McCormack M, Semprum-Prieto LC, Shenouda S, Majid DS, Kobori H, Navar LG and Prieto MC: AT1 receptor-mediated augmentation of angiotensinogen, oxidative stress, and inflammationin ANG II-salt hypertension. Am J Physiol Renal Physiol 302: F85-F94, 2012. 